VOX PATRUM 21 (2001) t. 40-41

Enrico DAL COVOLO

(Roma, Univ. Salesiana)

\title{
WYMOGI FORMACJI I TOŻSAMOŚCI KAPŁAŃSKIEJ Między Antiochią i Aleksandrią (II-IV wiek)
}

W naszym artykule chcemy zilustrować kilka dzieł okresu patrystyki odnoszących się do formacji i tożsamości kapłańskiej ${ }^{1}$. Ograniczymy się do kilku przykładów wśród wielu możliwych ${ }^{2}$, czerpiąc najpierw z tradycji antiocheńskiej, a następnie z tradycji aleksandryjskiej. Nasz wybór z jednej strony pragnie wprowadzić porządek przedstawienia, $z$ drugiej pozwala na przewartościowanie wyobrażania sobie teologii Ojców jako skamieniałego i skondensowanego monolitu. W rzeczywistości różnorodność starożytnych szkół Antiochii, Aleksandrii, Edessy i właściwych im korzeni historyczno-kulturowych niesie w sobie zróżnicowanie myśli i wrażliwości patrystycznej. Dobrze są znane orientacje starożytnych tradycji Antiochii i Aleksandrii. Z jednej strony Antiochia wydaje się ucieleśniać cechy tzw. „materializmu” azjatyckiego, promując znaczenie dosłowne w egzegezie i ludzką naturę Syna w chrystologii, podczas gdy Aleksandria przyjmuje raczej dwie instancje - odpowiednio się uzupełniające - alegorię w egzegezie i naturę boską Słowa w chrystologii ${ }^{3}$.

${ }^{1}$ Podejmiemy w szerszej perspektywie rezultaty publikacji M. Maritano, Formazione e ministero dei diaconi nelle Lettere di Ignazio d'Antiochia, w: L. Padovese (red.), Atti del VI Simposio di Tarso su S. Paolo Apostolo (= Turchia: la Chiesa e la sua storia 14), Roma 2000, 155-180 (bibliografia rozproszona, ale wyczerpująca), i udoskonalamy niektóre z naszych prac: E. Dal Covolo, Sacerdoti come i nostri Padri. I Padri della Chiesa maestri di formazione sacerdotale, Roma 1998 (tłum. hiszpańskie: Sacerdotes como nuestros Padres. Los Padres de la Iglesia, maestros de formación sacerdotal, Bogotae 2000); idem, Tra storia e teologia. La formazione al sacerdozio ministeriale. Antiochia - Alessandria (II-IV sec.), w: A. Russo-G. Coffele (red.), Divinarum Rerum Notitia. La teologia tra filosofia e storia. Studi in onore del Cardinale Walter Kasper, Roma 2001, 3-22. Jak wiadomo, temat formacji kapłańskiej u Ojców Kościoła nie był dotąd pogłębiony przez badaczy, przekonanych być może, ze w tym zakresie materiał jest zbyt skromny w swej wyrazistości. Tym bardziej cenną pozostaje praca: O. Pasquato, L'istituzione formativa del presbitero nel suo sviluppo storico (sec. I-XVI), „Salesianum” 58 (1996) 269-299 (bogata bibliografia), która służyła nam licznymi sugestiami.

${ }^{2}$ Wykaz najważniejszych tekstów patrystycznych dotyczących świętości, do której powołany jest prezbiter, znajduje się np. w: A. Trapé, Il sacerdote uomo di Dio al servizio della Chiesa. Considerazioni patristiche, Roma $1985^{2}, 41-42$.

${ }^{3}$ Dla pogłębienia tych kwestii por. E. Dal Covolo (red.), Storia della teologia, 1. Dalle origini 


\section{TRADYCJA ANTIOCHEŃSKA ${ }^{4}$}

1. Ignacy Antiocheński $(\dagger \mathbf{1 0 7})^{5}$. Ogólnie przyjętą jest tendencja, by uznawać Lucjana, mistrza Ariusza za założyciela szkoły w Antiochii. Już jednak Ignacy w 1. poł. II wieku antycypuje niektóre $\mathrm{z}$ jej cech charakterystycznych, przede wszystkim wyrazisty realizm jego wypowiedzi o naturze ludzkiej Chrystusa: „On jest prawdziwie z rodu Dawida”, pisze Ignacy do Smyrneńczyków, „prawdziwie narodzony z dziewicy..., prawdziwie przebity za nas”.

Ten sam realizm stosuje Ignacy, kiedy odnosi się do Kościoła, nawiązując w szczególności wiele razy do hierarchii kościelnej, gdy mówi o biskupach, prezbiterach i diakonach ${ }^{7}$ :

„Należy zatem, abyście postępowali zgodnie z myślą biskupa, co też czynicie. Wasi bowiem kapłani, słusznie szanowani i godni Boga, tak są zestrojeni z biskupem, jak struny z cytrą. Dlatego to wasza zgoda i harmonia miłości wyśpiewuje [światu] Jezusa Chrystusa. I niech każdy $\mathrm{z}$ was także włączy się w ów chór, abyście w harmonii waszej zgody, biorąc ton Boga w jedności, śpiewali jednym głosem Ojcu przez Jezusa Chrystusa" ${ }^{8}$.

I po tym jak polecał Smyrneńczykom, aby „,nie podejmowali żadnej decyzji związanej z Kościołem bez wiedzy ich biskupa", zwierza się Polikarpowi:

a Bernardo di Chiaravalle, Bologna - Roma 1995, 181-203 („Esegesi biblica e teologia tra Alessandria e Antiochia”) i s. 520, przypis 11. W szczególności o „teologii antiocheńskiej” por. D.S. Wallace-Hadrill, Christian Antioch. A study of Early Christian Thought in the East, Cambridge 1982; S. Zincone, Studi sulla visione dell'uomo in ambito antiocheno (Diodoro, Crisostomo, Teodoro, Teodoreto), L'Aquila - Roma 1988.

${ }^{4}$ Por. antologię tekstów i bibliografię wstẹpną: P. Chauvet et alii, Sacerdoce des baptisés, sacerdoce des prêtres. Textes de l'antiquité chrétienne de Tertullien à Pierre Damiani, Paris 1991; L. Padovese, I sacerdoti dei primi secoli. Testimonianze dei Padri sui ministeri ordinati, Casale Monferrato 1992; F. Rodero, El sacerdocio en los Padres de la Iglesia. Grandeza, Pequeñez y Ascesis. Antología de Textos, Madrid 1993; E. Cattaneo (red.), I ministeri nella Chiesa antica. Testi patristici dei primi tre secoli, Milano 1997, 211-215 (bibliografia).

5 Por. godne uwagi wprowadzenie do teologii Ignacego, autorstwa F. Bergamelliego w: G. Bosio - E. Dal Covolo - M. Maritano, Introduzione ai Padri della Chiesa. Secoli I e II, Torino $1998^{3}, 88-106$ (z bibliografią). Dla tematu, który nas interesuje, zob. także C. Riggi, Il sacerdozio ministeriale nel pensiero di Ignazio di Antiochia, w: S. Felici (red.), La formazione al sacerdozio ministeriale nella catechesi e nella testimonianza di vita dei Padri, Roma 1992, 39-57; M. Simonetti, Presbiteri e vescovi nella chiesa del I e II secolo, ,Vetera Christianorum” 33 (1996) 115-132.

6 Ad Smyrnenses 1,1, SCh 10, 132.

7 Por także J. Colson, Ministre de Jésus-Christ ou le sacerdoce de l'Évangile. Étude sur la condition sacerdotale des ministres chrétiens dans l'Église primitive, Paris 1966, który zauważa, że „dans le Corpus ignacien la tendance à «spiritualiser» les valeurs cultuelles et sacerdotales" (ibidem, s. 332), musi przyznać że kult chrześcijański wciela się w rzeczywistość „dans une société, dirigée par une hiérarchie fortement constituée, qui en est l'organisme visible” (ibidem, s. 334).

${ }^{8}$ Ad Ephesios 4,1-2, SCh 10, 60.

9 Ad Smyrnaeos 8, 1, SCh 10, 138. 
„Ja ofiaruję moje życie dla tych którzy są poddani biskupowi, prezbiterom i diakonom. Obym mógł razem z nimi mieć udział w Bogu. Pracujecie razem jedni dla drugich, walczycie razem, biegniecie razem, razem cierpicie, odpoczywacie i czuwacie razem jak administratorzy Boga, jego asesorzy i słudzy. Starajcie się podobać temu, dla którego podejmujecie walkę i od którego otrzymacie nagrodę. Niech nikt $z$ was nie będzie odstępcą. Wasz chrzest niech będzie jakby tarczą, wiara szyszakiem, miłość kopią, cierpliwość zbroją duchową"10.

W Listach Ignacego można zauważyć swoistą niezmienną i owocną dialektykę między dwoma aspektami charakteryzującymi życie chrześcijańskie: z jednej strony, bez wątpienia struktura hierarchiczna wspólnoty eklezjalnej, o której już mówiliśmy, z drugiej zaś fundamentalna jedność, która wiąże między sobą wszystkich wiernych w Chrystusie. W konsekwencji, niemożliwym jest przeciwstawienie sobie ról ${ }^{11}$. Przeciwnie, podkreślenie komunii wspólnoty i wzajemnej miłości wierzących wciąż formowane przez obrazy i analogie (cytra, struny, współbrzmienie, koncert), wydaje się być jakby świadomym przełożeniem wspólnej tożsamości wszystkich wiernych, bez znaczenia na fakt czy są kapłanami czy nie. Z drugiej strony, ewidentną pozostaje odpowiedzialność diakonów, prezbiterów i biskupów w budowaniu wspólnoty ${ }^{12}$. Ich przede wszystkim dotyczy zachęta do miłości i jedności:

„Wszystko róbcie wspólnie”, pisze Ignacy do Magnezjan podejmując modlitwę Jezusa z ostatniej Wieczerzy: ,Jedna modlitwa, jedna prośba, jeden duch, jedna nadzieja w miłości... Wszyscy więc biegnijcie, by zjednoczyć się jakby w jedną świątynię Boga, jakby wokół jednego ołtarza, w jednym Jezusie Chrystusie, który wyszedł od Ojca jedynego, który był w Nim jedyny i do Jedynego powrócil"13.

Ignacy nie wyznacza wymogów formacyjnych potrzebnych dla przyjęcia święceń, ale te nie przestają być oczywiste. By podać przykład Listu do Kościoła w Tralleis, w którym biskup, przyjmując nauczanie Dziejów Apostolskich 6 (święcenia pierwszych diakonów), wyjaśnia w szczerości słowa:

„Trzeba też, aby i diakoni, będący sługami tajemnic Jezusa Chrystusa, podobali się wszystkim na wszelki sposób. Nie są bowiem usługującymi przy jedzeniu i piciu, lecz sługami (huperetai: dosłownie „,wioślarze”) Kościoła Boga. Należy zatem, by wystrzegali się jak ognia wszelkich zarzutów"14.

${ }^{10}$ Ad Polycarpum 6,1-2, SCh 10, 150-152.

11 Por. E. Dal Covolo, Sacerdozio ministeriale e sacerdozio comune. La rilettura patristica di 1 Petri 2,9 nell'attuale dibattito sulle origini della distinzione gerarchica, w: S. Felici (red.), La formazione al sacerdozio ministeriale, s. 255-266.

${ }^{12}$ Por. E. Dal Covolo, Ministeri e missione alle origini della Chiesa, w: E. Dal Covolo - A.M. Triacca (red.), La missione del Redentore. Studi sull'Enciclica missionaria di Giovanni Paolo II, Torino 1992, 123-136.

${ }^{13}$ Ad Magnesios 7, 1-2, SCh 10, 84-86.

${ }^{14}$ Ad Trallanos 2, 3, SCh 10, 96. 
Możemy skonfrontować ten ostatni fragment Ignacego z obrazem diakona, jaki przekazują Dzieje Apostolskie. Diakoni, mówi się $\operatorname{tam}^{15}$, są ludźmi „cieszącymi się dobrą sławą", albo lepiej „ludźmi wypróbowanymi w świadectwie” (Dz 6, 3: martyroumenoi). Jak można zauważyć, słowo użyte przywołuje na myśl termin „męczennik”. Można powiedzieć, że diakon musi być „męczennikiem”, w tym sensie, że świadectwo jego diakonii nie może nigdy się zatrzymać, za cenę - jeśli to konieczne - nawet całego życia. W tym znaczeniu Ignacy stwierdza, że diakoni są sługami Kościoła i Boga. Po drugie, według Dziejów, diakon musi być „pełen Ducha i mądrości” (6, 3). Chodzi o mądrość, która pochodzi od Boga: „mądrość Ducha”, która wymaga głębokiej jedności z Panem. Tak więc, służba miłości - tzw. „obsługiwanie stołów”, dla której diakoni są ustanowieni - wymaga w ich życiu całkowitego pierwszeństwa wymiaru duchowego. Wracając do słów Ignacego, nie są oni tylko prostymi rozdzielcami pokarmu i napoju, ale są na służbie tajemnic Chrystusa. Jeśli duchowny nie formuje się w kontemplacji świętych tajemnic Chrystusa, aż do osiągnięcia z Nim ,jedności”, nie może sprawować autentycznej służby miłości i nie „umacnia” Kościoła Bożego.

2. Jan Chryzostom $\left(\dagger\right.$ 407) ${ }^{16}$. Przejdźmy teraz do innego Ojca antiocheńskiego, mistycznie rozkochanego w kapłaństwie. W tym przypadku, chciałbym przede wszystkim przedstawić Jana Chryzostoma, jako pasterza w akcji, uchwyconego w sprawowaniu swego pasterskiego powołania, „złapanego w ogniu" swej służby. Myślę o słynnych Homiliach na Ewangelię według świętego Mateusza i o sposobie, w jaki autor podejmował palące problemy, jak bogactwo i ubóstwo we wspólnocie chrześcijańskiej Antiochii. Homilie te powstałe około 350-407 r. są najstarszym komentarzem do pierwszej Ewangelii, jaki posiadamy. Przedstawiają też znaczące świadectwo tej aktywności homiletycznej, która zapewniła Chryzostomowi najwyższe uznanie wśród mówców kościelnych. Sięgają one czasu miedzy rokiem 386 a 397 - to znaczy między święceniami kapłańskimi w Antiochii a wyborem na katedrę patriarchy Konstantynopola - czasu, w którym Chryzostom podejmował zadania kaznodziei w najważniejszych kościołach antiocheńskich. Służba ta w szczególny sposób odpowiadała Janowi, który po doświadczeniach monastycznych i pustelniczych, przyjął kapłaństwo wypełniając powołanie duszpasterskie, któremu nie podobna było się oprzeć ${ }^{17}$, i które właśnie przez przepowiadanie Pisma św. pragnął

15 Jak wiadomo, choć, termin ten nie pojawia się w opowiadaniu Dziejów Apostolskich, to w każdym razie - pomijając użytą terminologię - nie można zaprzeczyć, że „siedmiu” piastowało urząd diakonów.

${ }^{16}$ Dobre wprowadzenie do dzieł Chryzostoma, autorstwa O. Pasquato, zob. w: G. Bosio E. Dal Covolo - M. Maritano, Introduzione ai Padri della Chiesa. Secoli III e IV, Torino 1998², 390435 (z bibliografią).

17 Por. O. Pasquato, Ideale sacerdotale e formazione al sacerdozio del giovane Crisostomo: evoluzione o continuità?, w: S. Felici (red.), La formazione al sacerdozio ministeriale, s. 59-93. 
realizować: ściśle związane ze sobą przepowiadanie i egzegeza - wierne podstawowym wskazaniom szkoły antiocheńskiej - wydają się być szczególnie wyczulone na konkretne sytuacje życiowe, na problemy i potrzeby także materialne swoich słuchaczy. Szczególnie w Antiochii 2. poł. IV wieku, gdzie były olbrzymie różnice społeczne i ekonomiczne z powodu wojen, latyfundiów, kapitalizmu, niesprawiedliwego systemu fiskalnego, Chryzostom jest bez ustanku mobilizowany do traktowania różnorodnych problemów powstających w życiu wspólnotowym bogatych i ubogich ${ }^{18}$; wystarczy wspomnieć, że w samych tylko homiliach na Ewangelię Mateusza temat ten powraca nie mniej niż sto razy!

Zechciejmy więc posłuchać „pasterza w ogniu służby” czytając niektóre fragmenty z jego pięćdziesiątej homilii na Ewangelię według świętego Mateu$\mathrm{sza}^{19}$. Homilia ta komentuje perykopę zamykającą 14 rozdział Mateusza, ale ostatni werset - gdzie czytamy jak mieszkańcy Genezaret przynosili do Jezusa swoich chorych „, prosili, żeby przynajmniej frędzli Jego płaszcza mogli się dotknąć" (Mt 14, 36) - pozwala Chryzostomowi rozszerzyć perspektywę parenetyczną, która sama zajmuje drugą połowę kazania. Owo poszerzenie, zasadniczo niezależne, tłumaczy się kontekstem liturgii eucharystycznej, w której ma miejsce homilia: „Dotknijmy i my frędzli Jego płaszcza”, zachęca Chryzostom; "co więcej, jeśli chcemy, mamy Chrystusa całego. Jego ciało jest teraz prawdziwie przed nami”. I dodaje: „Wierzycie, że także teraz mamy ten stół, przy którym Jezus zasiadł" 20 . Według Chryzostoma, taka pewność wiary w sposób decydujący odwołuje się do odpowiedzialności wiernych, jako że uczestnictwo w stole Pana nie dopuszcza niewierności: „żeby żaden Judasz nie przybliżał się do stołu!" - woła kaznodzieja. I nie jest wystarczającym kryterium przystąpienia do ołtarza z naczyniami ze złota:
„Ani ze srebra nie był stół, ani ze złota nie był kielich, z którego Chrystus dał uczniom swoją krewPragniesz uczcié ciało Chrystusa? Nie pozwól, by było ono nagim: nie czcij go tu w świątyni w stroju drogocennym, by jednocześnie na zewnątrz tolerować, że on umiera z zimna i głodu. Ten, który powiedział: «To jest ciało moje», powiedział także: «widzieliście mnie głodnym, a nie daliście mi jeść» $\mathrm{i}$ «co uczyniliście jednemu z tych braci moich najmniejszych, mnieście uczy- nili». Uczmy się więc czcić Chrystusa tak, jak On tego pragnie, rozdając bogactwa między ubogich. Bóg nie potrzebuje złotych sprzętów, ale złotych dusz. Jaka

${ }^{18}$ Por. S. Zincone, Ricchezza e povertà nelle omelie di Giovanni Crisostomo, L'Aquila 1973; A. Olivar, I poveri alle porte delle chiese nella predicazione del IV secolo, w: E. Manicardi F. Ruggiero (red.), Liturgia ed evangelizzazione nell'epoca dei Padri e nella Chiesa del Vaticano II. Studi in onore di Enzo Lodi, Bologna 1996, 219-235; E. Dal Covolo, Le catechesi battesimali di san Giovanni Crisostomo, ,,Salesianum” 63 (2001) 157-167.

19 Por. E. Dal Covolo, I Padri della Chiesa e la „Sollicitudo Rei Socialis”, w: M. Toso (red.), Solidarietà. Nuovo nome della pace. Studi sull'Enciclica „Sollicitudo Rei Socialis” di Giovanni Paolo II, Torino 1988, 15-27.

20 In Matthaeum hom. 50, 2-3, PG 58, 507. 
bowiem korzyść jest $\mathrm{z}$ tego, że ołtarz jest pełen złotych kielichów, kiedy on sam umiera z głodu? Najpierw nakarm Go, który jest głodnym, a potem z nadmiaru przystroisz Jego ołtarz!"21.

Cytowane słowa są wystarczająco wyraziste, by ukazać pełne utożsamienie się Chrystusa z potrzebującym. Chryzostom istotnie jest świadom, że przed jakimkolwiek uściśleniem zasad, obowiązuje ta podstawowa: kto służy ubogim, służy Chrystusowi, kto odrzuca ubogiego, odrzuca Chrystusa. Z tego będziemy sądzeni (Mt 25, 31-46). Ale Chryzostom jest równie świadomy, że taka miłość bliźniego - aby rzeczywiście mogła odzwierciedlać miłość do Chrystusa - musi karmić się wspólnotą z Bogiem i jego miłością ku nam.

W swoim przepowiadaniu biskup podkreśla $\mathrm{z}$ naciskiem głęboką więź między przykazaniem miłości a życiem Bożym. Autentyczny świadek miłości musi móc powtarzać razem z apostołem Janem: „To, na co patrzyliśmy, to jest Słowo życia, wam oznajmiamy!" (1J 1, 1-4). Innymi słowy, by wzrastać w autentycznej miłości, wierni, a o ileż bardziej duchowni, muszą znać Jezusa, żyć w jego bliskości ${ }^{22}$. Jeszcze raz kaznodzieja powraca do „wymiaru kontemplacyjnego" prezbitera i do jakości jego spotkania z Panem w Słowie i sakramentach.

W tej perspektywie może być odczytany także słynny Dialog z Bazylim, zredagowany około 390 roku $^{23}$, gdzie Jan Chryzostom mówi o „dobrym przykładzie" i o „słowie" jako lekarstwach prezbitera:

„Lekarze ludzkich ciał wynaleźli wiele lekarstw... Tutaj zaś nic podobnego nie można wymyśleć. Poza dobrym przykładem jeden tylko pozostaje środek, jedna droga do wyleczenia - pouczenie przez słowo" 24 .

W tym samym Dialogu Chryzostom mówi o kapłaństwie jako o „życiu pełnym odwagi i poświęcenia”, bo urząd (prawdziwego) pasterza nie zna ciasnych granic własnej opłacalności, ale obraca się zawsze na korzyść całej owczar$\mathrm{ni}^{25}$.

21 Tamże 50, 3-4, PG 58, 508-509.

22 Por. przykładowo In Joannem hom. 46, 3, PG 59, 260: „By stać się jednym ciałem nie tylko przez miłość, ale w rzeczywistości, trzeba zjednoczyć się w jego ciele, czego dostępuje się przez spożywanie Jego ciała, które nam zostawił na znak swej wielkiej miłości do nas. Przeniknął nas do głębi, aż do uformowania jednego ciała dlatego, byśmy byli jedno z nim, tak jak jednością jest ciało z jego głową. To jest znak największej miłości".

${ }^{23}$ Por. F. Marinelli, La carta del prete. Guida alla lettura del «Dialogo sul sacerdozio» di San Giovanni Crisostomo, Roma 1986; M. Lochbrunner, Über das Priestertum. Historische und systematische Untersuchung zum Priesterbild des Johannes Chrysostomus, Bonn 1993.

${ }^{24}$ Dialogus de sacerdotio IV 3, 5-13, ed. M. Malingrey, SCh 272, 248-250.

${ }^{25}$ Por tamże II 4, 51-64, SCh 272, 116-118: odniesienie dotyczy przede wszystkim wyrażenia ghennaia psyché, w znaczeniu, jakie przyjmuje w słownictwie chrześcijańskim, a u Chryzostoma w szczególności (zob. tamże, s. 117, przypis 3). 
Według Chryzostoma troska o owczarnię jest „znakiem miłości”, jest najwymowniejszym dowodem tego, że pasterz miłuje prawdziwie Pana: „Jeśli mnie miłujesz, paś owce moje...”. Przy tej okazji, zauważa Chryzostom, że Mistrz zapytał ucznia, czy go miłuje, nie po to żeby się dowiedzieć, bo dlaczego miałby to robić, skoro przenika i zna serca wszystkich. Ani nawet ,nie chodziło mu wtedy o pokazanie, jak go Piotr miłował, bo było to już wiadome $z$ wielu miejsc; lecz chciał pouczyć Piotra i nas wszystkich, jak on (Pan nasz) kocha swój Kościół, abyśmy i my z całą gorliwością oddali się na jego służbę"26. I w tym właśnie znajduje się różnica nie do pokonania, między „najemnikiem” a „pasterzem”: „dobry Pasterz daje życie swoje za owce” (J 10, 11).

3. Pierwsze konkluzje. Ma się wrażenie, że tak Ignacy, jak i Jan Chryzostom podkreślają bardziej aspekt tożsamości i misji prezbitera, niż proces jego formacji. W większości przypadków, rzeczywiście, wymogi formacyjne pozostają tylko w domyśle. U obu Ojców, mimo wszystko, mogliśmy dostrzec silne podkreślenie koniecznej jedności prezbitera z Chrystusem. Dla obydwu Antiocheńczyków, ponadto, doskonała jedność z Chrystusem i catkowite oddanie owczarni nie wydają się być jedynie dwoma cechami charakteryzującymi prezbitera (do zdobycia których, w konsekwencji, będzie niezmiennie ukierunkowany proces formacji kapłańskiej). One stanowią jedną i tę samą rzeczywistość. Są jak dwie strony tego samego medalu. Jedna stanowi o prawdzie drugiej, i nie może mieć miejsca przypadek kapłana, który pielęgnowałby jedną tylko cechę bez drugiej. Dla prezbitera całkowite oddanie owczarni jest znakiem jego zjednoczenia $\mathrm{z}$ Chrystusem. Z drugiej strony jego pełne poświęcenie dla owczarni zobowiązuje go „by pośpieszać” wciąż „do Jezusa Chrystusa jako do jedynej świątyni Boga, jak do jedynego ołtarza".

Zważywszy to wszystko, ,realizm” Ojców antiocheńskich zachęca prezbitera do progresywnej syntezy między konfiguracja ku Chrystusowi (zażyłość, jedność z nim) i poświęceniem duszpasterskim (misja, służba Kościołowi i światu), aż do momentu, w którym jeden wymiar przemawiać będzie przez drugi i kapłani nie ograniczą się do bycia ,,jedynie dystrybutorami”, ale będą „autentycznymi świadkami” tajemnic Chrystusa i jego Kościoła.

\section{TRADYCJA ALEKSANDRYJSKA: ORYGENES ${ }^{27}$}

Przejdę ostatecznie do tak zwanej „tradycji aleksandryjskiej”. Już zauważyliśmy, że Aleksandria wydaje się przyjmować dwie komplementarne cechy odróżniające ją od tradycji antiocheńskiej, to znaczy alegorię w egzegezie

\footnotetext{
${ }^{26}$ Tamże II 1, 35-40, SCh 272, 102.

${ }^{27}$ Por. antologię tekstów i bibliografię wprowadzającą wyżej, przypis 4 .
} 
i podkreślenie bóstwa Słowa w chrystologii. Ogólnie mówiąc, Aleksandria jest bardzo odległa od tak zwanego „materializmu” azjatyckiego, o którym wspominaliśmy na początku: jest to widoczne także w granicach eklezjologii, a w szczególności, w teorii stanu duchownego ${ }^{28}$.

Dla zilustrowania orientacji aleksandryjskiej na temat formacji kapłańskiej, ograniczę się do jednego tylko przykładu, skądinąd bardzo reprezentatywnego, a mianowicie - do Orygenesa, a przede wszystkim do jego Homilii o Księdze Kapłańskiej, wygłoszonych w Cezarei Palestyńskiej między 239 a 242 rokiem $^{29}$. Sytuują się one już parę lat po jego wielkim kryzysie, który - z powodu święceń kapłańskich udzielonych mu ok. 231 r. przez biskupa Cezarei bez wiedzy biskupa Aleksandrii - poróżnił Orygenesa i jego ordynariusza, biskupa Demetriosa. Kryzys pozostał otwarty i przyczynił się do przeniesienia Orygenesa do Cezarei ${ }^{30}$.

Trzeba przede wszystkim przyznać, że Orygenes $(\dagger 254)^{31}$, jako wierny Aleksandryjczyk, jest bardziej zainteresowany kontemplowaniem Kościoła w aspekcie duchowym, jako mistycznego Ciała Chrystusa, niż w jego wymiarze widzialnym. Dlatego też jest on bardziej wyczulony na tak zwaną „,hierarchię świętości”, niż na „hierarchię widzialną”: ta pierwsza odnosi się do nieustannej drogi ku doskonałości, otwartej dla każdego chrześcijanina. W konsekwencji, Aleksandryjczyk częściej mówi o kapłaństwie powszechnym wiernych i jego cechach charakterystycznych, niż o kapłaństwie hierarchicznym ${ }^{32}$. W każdym

${ }^{28}$ Chodzi tu naturalnie o podkreślenie, a nie o nauczanie jednostronne i wyłączne, co ukazuje np. fakt, że Orygenes, mistrz alegorii i interpretacji duchowej Pisma świętego, jest uczonym uważnym, nie mniej od innych, także na znaczenie dosłowne tekstu natchnionego. Dla pogłębienia tego rodzaju kwestii odsyłam raz jeszcze do E. Dal Covolo (red.), Storia della teologia, s. 181-203 (Esegesi biblica e teologia tra Alessandria e Antiochia) i s. 520, przypis 11; zob. ponadto H. Crouzel, La Scuola di Alessandria e le sue vicissitudini, w: Istituto Patristico «Augustinianum» (red.), Storia della teologia, 1: Età patristica, Casale Monferrato 1993, 179-223; J.J. Fernández Sangrador, Los origenes de la comunidad cristiana de Alejandrí, Salamanca 1994.

${ }^{29}$ Por. M. Maritano, Rassegna bibliografica su «Origene omileta», w: E. Dal Covolo L. Perrone (red.), Mosè ci viene letto nella Chiesa. Lettura delle Omelie di Origene sulla Genesi, Roma 1999, 141-162.

${ }^{30}$ Co do święceń kapłańskich Orygenesa zob. M. Szram, Problem święceń kapłańskich Orygenesa, VoxP 10 (1990) z. 19, 659-670; E. Cattaneo, I ministeri nella Chiesa antica, s. 360-362.

31 Jako wprowadzenie do Orygenesa, poza książką H. Crouzela, Origene, Paris 1985, Roma 1986, zob. też M. Maritano, w: G. Bosio - E. Dal Covolo - M. Maritano, Introduzione ai Padri della Chiesa. Secoli II e III, Torino $1998^{3}, 290-395$ (z bibliografią).

${ }^{32}$ Poza publikacjami J. Lécuyer i A. Vilela (cytowani poniżej, przypis 43), o kapłaństwie u Orygenesa por. przede wszystkim: H.U. von Balthasar, Parole et mystère chez Origène, Paris 1957, 86-94 (tłumaczenie włoskie: Origene - il mondo, Cristo e la Chiesa, Milano 1972, 60-65), do którego Vilela często się odnosi; Th. Schäfer, Das Priester-Bild im Leben und Werk des Origenes, Frankfurt 1977; syntetyczne H. Crouzel, Origene, s. 299-301, a także L. Padovese, I sacerdoti dei primi secoli, s. 52-66; zob. też A. Quacquarelli, I fondamenti della teologia comunitaria in Origene: il sacerdozio dei fedeli, w: S. Felici (red.), Sacerdozio battesimale e formazione teologica nella catechesi e nella testimonianza di vita dei Padri, Roma 1992, 51-59; Th. Hermans, Origène. Théologie sacrificielle du sacerdoce des chrétiens, Paris 1996. 
razie, podążając śladem wypowiedzi Orygenesa dotyczących obu tych argumentów ${ }^{33}$, nie będzie nam trudno odkryć kilka wskazówek na temat procesu formacji prezbiterów.

\section{Kapłaństwo powszechne wiernych i warunki jego wypełniania. Długa} lista tekstów Orygenesowych stara się zilustrować warunki wymagane dla wypełniania kapłaństwa powszechnego ${ }^{34}$. W dziewiątej homilii o Księdze Kapłańskiej Orygenes - odwołując się do danego Aaronowi, po śmierci jego dwóch synów, zakazu wchodzenia do sancta sanctorum „w każdym czasie” (Kpł 16, 2) - przestrzega:

„Jeśli ktoś wejdzie o jakiejkolwiek porze do miejsca świętego, bez odpowiedniego przygotowania, nie odziany w szaty arcykapłańskie, bez uprzedniego przygotowania ofiary nakazanej dla właściwego przedstawienia się Bogu, umrze... Ta przestroga dotyczy nas wszystkich: poucza nas ona bowiem, abyśmy wiedzieli, jak powinniśmy przystępować do ołtarza Boga. Czyż nie wiesz, że i tobie, to znaczy całemu Kościołowi Bożemu i ludowi wierzących, dano godność kapłańską? Posłuchaj, co Piotr mówi o wiernych: «[jesteście] plemieniem wybranym, królewskim, kapłańskim, narodem świętym, ludem Bogu na własność przeznaczonym». Posiadasz przeto godność kapłańską, ponieważ jesteś «plemieniem kapłańskim», a więc powinieneś składać Bogu ofiarę uwielbienia, ofiarę modlitwy, ofiarę miłosierdzia, ofiarę czystości, ofiarę sprawiedliwości i ofiarę świętości. Po to jednak, abyś mógł godnie złożyć te ofiary, potrzebujesz czystych szat, różnych od zwykłej odzieży innych ludzi, i koniecznym ci będzie ogień Boży - nie jakiś ogień obcy Bogu, ale ten, który Bóg udzielił ludziom - o którym mówi Syn Boży: «Przyszedłem ogień rzucić na ziemię» (Łk 12, 49)"35.

Także w czwartej homilii, mając na uwadze prawodawstwo lewickie, według którego ogień na ofiarę całopalną musiał płonąć na ołtarzu nieustannie (Kpł 6, 2-13), Orygenes wzywa swoich wiernych:

„Posłuchaj: ogień wciąż powinien płonąć na ołtarzu. I ty, jeśli chcesz być kapłanem Boga - zgodnie z tym, co jest napisane: «Wy wszyscy będziecie kapłanami Pana» (Iz 61, 6), wszak i do ciebie zostało powiedziane: «[jesteście] plemieniem wybranym, królewskim kapłaństwem, ludem Bogu na własność przeznaczonym» (1P 2, 9) - jeśli zatem pragniesz sprawować funkcje kapłańskie względem twojej duszy, nie pozwól nigdy, by zniknął ogień duchowy z twego ołtarza” ${ }^{36}$.

33 Por. także E. Dal Covolo, Sacerdozio, w: A. Monaci Castagno (red.), Origene. Dizionario. La cultura, il pensiero, le opere, Roma 2000, 419-422.

${ }^{34}$ Chodzi o teksty, które w większości przypadków odwołują się w sposób wyraźny albo domyślny do 1P 2, 9: „Wy jesteście wybranym plemieniem, królewskim kapłaństwem...”. Por. E. Dal Covolo, L'interpretazione origeniana di 1 Petri 2, 9, w: G. Dorival - A. Le Boulluec (red.), Origeniana Sexta. Origène et la Bible / Origen and the Bible, Leuven 1995, 567-575.

35 In Leviticum hom. 9, 1, ed. M. Borret, SCh 287, 72-74.

36 Tamże, hom. 4, 6, SCh 286, 180. 
Jak widać, Aleksandryjczyk przywołuje warunki duchowe, które czynią wiernych mniej lub bardziej godnymi sprawowania kapłaństwa powszechnego. Dodaje bowiem w tej samej homilii: „oznaczają one to, co Pan nakazuje w Ewangelii, «niech będą przepasane wasze biodra i zapalone pochodnie» (Łk 12, 35). Niech będzie zawsze zapalony w tobie ogień wiary i kaganek mądrości”, ${ }^{37}$. Ostatecznie, z jednej strony ,przepasane biodra”38 i „szaty kapłańskie”, oznaczające czystość i cnotę życia, z drugiej zaś ,,pochodnia zawsze zapalona", oznaczająca wiarę i znajomość Pisma, wyrażają warunki niezbędne do wykonywania kapłaństwa powszechnego. O ileż bardziej są one warunkami koniecznymi dla sprawowania kapłaństwa hierarchicznego: co więcej, w myśli Orygenesowej stanowią one „kamienie milowe” formacji prezbiterów. Ale do tego powrócimy w naszych konkluzjach.

2. Kapłaństwo wiernych i przyjmowanie Słowa. Bardziej niż „przepasane biodra”, Orygenes podkreśla z mocą „zapalone pochodnie”, to jest przyjmowanie i zgłębianie Słowa Bożego. Czyni to w siódmej homilii do Księgi Jozuego:

„Mury Jerycha walą się na głos trąb kapłanów... Dzięki wierze ty masz w sobie Jozuego [= Jezusa] jako przewodnika. Jeśli jesteś kapłanem, zrób sobie „trąby kute" (tubae ductiles); albo raczej, o ile jesteś kapłanem - a rzeczywiście jesteś „plemieniem kapłańskim”, i o tobie powiedziano, że jesteś „,kapłaństwem świętym” - uczyń sobie „,trąby kute” z Pisma Świętego, skąd wydobędziesz ( $d u c$ ) różne myśli i słowa, i stąd będzie twoje przepowiadanie; właśnie dlatego one są nazywane tubae ductiles. I dmij w te trąby, to znaczy śpiewaj psalmy, hymny i pieśni pełne ducha, wyśpiewuj nauczanie prorockie i przepisy prawa, i naukę apostołów”39.

W trzeciej zaś homilii do Księgi Rodzaju, odnośnie zdania „lud, który Bóg sobie wybrał musi przyjąć we własnych uszach należne obrzezanie przez Słowo Boże" Orygenes stwierdza:

„Wy, «ludu Boga» $(1 \mathrm{P} 2,10)$, «narodzie wybrany na własność, aby ogłaszać dzieła potęgi Pana» $(1 \mathrm{P} 2,9)$ przyjmijcie godne obrzezanie przez Słowo Boga do waszych

${ }^{37}$ Tamże.

${ }^{38}$ Dla głębszego zrozumienia interpretacji Orygenesowej ,przepasanych bioder” użytecznym będzie przypomnienie fragmentu z pierwszego traktatu Pascha odkrytego w Tura w 1941 roku, w którym Aleksandryjczyk tłumaczy znaczenie „przepasanych bioder” na wieczerzę paschalną (Wj 12,11). „Zostało nam nakazane”, komentuje Orygenes, „być nieskażonymi od spotkań cielesnych, co oznacza pas na biodrach. [Biblia] uczy nas przewiązać miejsce płciowości i nakazuje powstrzymywanie bodźców seksualnych, podczas gdy jesteśmy częścią ciała Chrystusa" (O. Guéraud - P. Nautin, Origène. Sur la Pâque. Traité inédit publié d'après un papyrus de Toura, Paris 1979, 74, thum. włoskie opatrzone komentarzem: G. Sgherri, Origene. Sulla Pasqua. Il papiro di Tura, Milano 1989, 107; zob. także E. Dal Covolo, Origene: sulla Pasqua, „Ricerche Teologiche” 2:1991, 207-221).

${ }^{39}$ In Jesu Nave hom. 7, 2, ed. A. Jaubert, SCh 71, 200. 
uszu i do waszych ust, i w waszego serca, i do waszego ciała, i w ogóle do wszystkich waszych członków"40.

„Ty, ludu Boga”, dodaje jeszcze Orygenes w innym kontekście, ,,jesteś powołany do słuchania Słowa Bożego, nie jako plebs (lud), ale jako rex (król). Do ciebie przecież powiedziano: „Plemię królewskie i kapłańskie, ludu, który Bóg sobie wybrał" 41 .

Przyjęcie Pisma jest decydujące dla pełnego uczestnictwa w „plemieniu kapłańskim”. Interpretując alegorycznie Księgę Ezechiela 17, Orygenes ilustruje swoim wiernym dwie możliwości, sobie przeciwstawne: przymierze z Nabuchodonozorem - naznaczone przekleństwem i wygnaniem - właściwe temu, kto odrzuca Słowo; albo przymierze z Bogiem, którego znakiem rozpoznawczym jest właśnie przyjęcie Pisma Świętego. To przymierze naznaczone jest błogosławieństwem i obietnicą:

„My wszyscy, którzy przyjęliśmy Słowo Boże, jesteśmy królewskim potomstwem (regium semen). Rzeczywiście jesteśmy nazwani «plemieniem wybranym i królewskim kapłaństwem, narodem świętym, ludem Bogu na własność przeznaczonym» ${ }^{\prime 42}$.

3. Kapłaństwo powszechne wiernych i ,hierarchia świętości”. Te warunki nieskazitelnego postępowania w życiu, ale przede wszystkim przyjmowania i zgłębiania Słowa - stanowią prawdziwą „hierarchię świętości” ${ }^{33}$ w kapłaństwie powszechnym chrześcijan. Dla przykładu, Orygenes myśli wyraźnie o ,hierarchii zasług duchowych”, o wiele częściej niż o „,hierarchii widzialnej”, kiedy, zamykając w czwartej homilii do Księgi Liczb wyjaśnienie spisu i posług liturgicznych lewitów ( $\mathrm{Lb} 4)$, twierdzi:

„Dlatego że taki właśnie jest sposób, w jaki Bóg udziela swoich tajemnic i kieruje służbą w świętych przybytkach, musimy okazać się takimi, abyśmy stali się godni przynależności do stanu kapłańskiego... My jesteśmy rzeczywiście «narodem świę-

${ }^{40}$ In Genesim hom. 3, 5, ed. L. Doutreleau, SCh 7bis, 130. Fragment ten przywołuje kilka aspektów doktryny Orygenesowej o znaczeniu duchowym tekstu natchionego, por. K. Rahner, I „sensi spirituali” secondo Origene, w: tegoż, Teologia dell'esperienza dello Spirito, Roma 1978, 133-163. Ogólniej zaś co do egzegezy Orygenesowej zob. T. Heither, Origenes als Exeget. Ein Forschungsüberblick, w: G. Schöllgen - C. Scholten (red.), Stimuli. Esegese und ihre Hermeneutik in Antike und Christentum. Festschrift für Ernst Dassmann (= Jahrbuch für Antike und Christentum 23), Münster Westfalen 1996, 141-153.

${ }^{41}$ In Judices hom. 6, 3, ed. P. Messié - L. Neyrand - M. Borret, SCh 389, 158. A z drugiej strony, według Orygenesa jest kapłanem każdy, kto posiadł znajomość prawa Bożego, ,et, ut breviter explicem, qui legem et secundum spiritum et secundum litteram novit" (In Leviticum hom. 6, 3, ed. M. Borret, SCh 286, 280).

${ }^{42}$ In Ezechielem hom. 12, 3, ed. M. Borret, SCh 352, 386.

${ }^{43}$ Por. J. Lécuyer, Sacerdoce des fidèles et sacerdoce ministériel chez Origène, ,Vetera Christianorum" 7 (1970) 259; A. Vilela, La condition collégiale des prêtres au III siècle, Paris 1971, 79-83. 
tym, królewskim kapłaństwem, ludem Bogu przeznaczonym» (1P 2, 9), dlatego, jeśli odpowiadamy zasługami naszego życia na otrzymaną łaskę, jesteśmy uznani za godnych pełnienia świętej służby" ${ }^{44}$.

W następnej piątej homilii o Księdze Liczb, podejmując ryzykowną próbę śmiałej interpretacji tekstu (Lb 4, 7-9), odczytuje on w sposób alegoryczny różne elementy, które składają się na „namiot świadectwa”. Można tu uchwycić jeszcze parę aluzji do „hierarchii świętości” kiedy kaznodzieja oświadcza, że „w tym namiocie znajdują się”, to jest w Kościele Boga żyjącego, „osoby doskonalsze w zasługach i wyższe laską". W każdym razie, wszyscy wierni jako całość tworzą „resztę Izraela”, to jest lud świętych, który aniołowie noszą na swych rękach aby nie uraził swej nogi o kamień, i mógł wejść do miejsca obiecanego. Mimo surowych zabezpieczeń lewickich, każdemu z nich wolno jest kontemplować bez obawy o świętokradztwo niektóre aspekty tajemnicy Boga, bo wszyscy razem są nazywani ,plemieniem i kapłaństwem królewskim, narodem świętym, ludem Bogu na własność przeznaczony" ${ }^{\text {"45. }}$

Także w homiliach o Księdze Liczb znajdujemy słynną Orygenesową interpretację studni Beer, „o której Pan powiedział do Mojżesza: «Zgromadź lud, a ja mu dam wodę». Śpiewali wtedy Izraelici pieśń następującą: «Tryskaj, źródło: opiewajcie je! Studnia, którą kopali książęta i królowie drążyli berłem i swymi laskami» (Lb 21, 16-18)". Orygenes widzi w tej studni samego Jezusa Chrystusa, źródło Słowa, i w nawiązaniu do książąt i naczelników ludu widzi różne stopnie wtajemniczenia w lekturę i wyjaśnianie Pisma. Jeśli trzeba by odróżnić książąt od naczelników ludu, Orygenes proponuje dostrzec w ksiązętach - proroków, a w królach - apostołów. „To zaś, że apostołów można nazywać królami”, wyjaśnia Aleksandryjczyk, „łatwo wywnioskować z tego, co się mówi o wszystkich wierzących: «Wy jesteście królewskim plemieniem, najwyższym kapłaństwem, narodem świętym»"46.

Pozostaje nam potwierdzić, że dla Orygenesa hierarchią najprawdziwszą jest ta, która opiera się na różnych poziomach przyjęcia Pisma, natomiast pozostaje w domyśle - przynajmniej w ostatniej cytowanej homilii - że odniesienie do Słowa Bożego jest nieodzowne dla wypełniania „królewskiego kapłaństwa" wspólnego wszystkim wiernym.

4. „Hierarchia duchownych”. W swoich homiliach Orygenes odnosi się wyraźnie do biskupów, prezbiterów i diakonów. Jego zdaniem, owa ,widzialna hierarchia” musi reprezentować w oczach wiernych „niewidzialną hierar-

${ }^{44}$ In Numeros hom. IV 3, 4, ed. L. Doutreleau - A. Méhat - M. Borret, SCh 415, 112; por. tamże, s. 113, przypis 1: „Origène songe plus à la hiérarchie des mérites qu'à la hiérarchie visible”.

${ }^{45}$ In Numeros hom. V 3, 1, ed. L. Doutreleau - A. Méhat - M. Borret, SCh 415, 130.

46 Tamże, hom. XII 2, 4, ed. L. Doutreleau, SCh 442, 90. 
chię" świętości. Innymi słowy, w nauczaniu Orygenesa święcenia kapłańskie i świętość muszą kroczyć tym samym krokiem. Ilustrując znaczenie humerału, „symbolu dobrych czynów”, Orygenes wzywa wiernych do zgodności mowy i czynów:

" «Ten ornament», to znak tych, którzy poczynili takie postępy, iż zasługują na to, aby przewodniczyć ludowi ${ }^{47}$ [...]. Kapłani, powinni przeglądać się w normach Prawa Bożego jakby w zwierciadle, i na ich podstawie rozpoznawać stopień ich zasług: czy są przybrani w szaty pontyfikalne..., czy wydaje im się być na wysokości [ich powołania] w mądrości, w czynach, w nauczaniu; jeśli tak, mogą uważać, że osiągnęli najwyższą godność ich kapłaństwa nie tylko z imienia, ale także ze swych efektywnych zasług. W przeciwnym razie niech zdają sobie sprawę, że dano im niższą godność, nawet jeśli otrzymali imię świadczące o wyższej godności”"48.

Jak widać, najwyższe poważanie względem stanu duchownego czyni Orygenesa bardzo wymagającym, prawie radykalnym, wobec poświęconych stanowi duchownemu. Dlatego też przestrzega każdego, kto śpieszy się „ku tym godnościom, które pochodzą od Boga, ku przewodniczeniu i szafarstwu w Kościele" ${ }^{49}$. I w drugiej homilii o Księdze Liczb zapytuje z bólem:
"Czy myślisz, że ci którzy mają tytuł kapłanów, chlubią się przynależnością do stanu kapłańskiego, postępują według zasad ich stanu, i czynią wszystko czego wymaga ich urząd? I tak samo, czy sądzisz, że diakoni postępują według porząd- ku, który wynika $z$ ich święceń? Skąd więc przychodzi nam słyszeć, jak ludzie często się skarżą, i mówią: «Patrz, jakiż to biskup, jaki to prezbiter, jaki dia- kon...»? Czy nie mówią tak tylko dlatego, że dostrzegają, jak duchowny nie wy- wiązuje się z obowiązków swego stanu?"50.

Tak oto w swoich homiliach nie waha się Orygenes ganić otwarcie najbardziej rażących wad kapłanów swego czasu. Stąd wynurza się i dla nas „negatywny” obraz niebezpieczeństw, których trzeba się wystrzegać w formacji prezbiterów.

Słabym punktem duchownych jest, zdaniem Orygenesa, pragnienie pieniądza i dóbr ziemskich, słowem - pokusa mieszczańskich przyzwyczajeń i zaostrzonego horyzontalizmu. Ubolewa, że duchowni dają się pochłonąć troskom doczesnym, i nie pragną czego innego, jak tylko pędzić życie doczesne "myśląc o sprawach tego świata, o zyskach doczesnych i o dobrej strawie" W innym kontekście dodaje: ,wśród nas duchownych znajdzie się taki, co wszystko czyni, żeby zadowolić własny brzuch, żeby być poważanym i dla swej korzyści obracać ofiary przeznaczone dla Kościoła. Oto ci, co o niczym innym

\footnotetext{
${ }^{47}$ In Exodum hom. 13, 7, ed. M. Borret, SCh 321, 398.

48 In Leviticum hom. 6, 6, ed. M. Borret, SCh 286, 290-292.

49 In Isaiam hom. 6, 1, ed. W.A. Baehrens, GCS 33, 269.

${ }^{50}$ In Numeros hom. II 1, 4, ed. L. Doutreleau - A. Méhat - M. Borret, SCh 415, 58-60.

51 In Ezechielem hom. 3, 7, ed. M. Borret, SC 352, 140.
} 
nie mówią, jak o brzuchu, i którzy stamtąd wydobywają każde słowo" ${ }^{2}$. Orygenes wyrzuca kapłanom także karierowiczostwo, arogancję i pychę:

„Czasem, znajdują się niekiedy wśród nas - postawionych jako wzór pokory i umieszczonych wokół ołtarza Pana jako zwierciadło dla tych, którzy na nas patrzą - niektórzy, od których cuchnie grzechem zuchwalstwa. Tak zapach odrzucający pychy roznosi się od ołtarza Pana ${ }^{53}$ [...]. Jakże wielu kapłanów zapomniało o pokorze! Tak jakby byli wyświęceni dlatego właśnie, by wyzbyć się pokory! [...]. Ustanowili cię przywódcą: nie wynoś się nad innych, ale bądź wśród twoich [braci] jak jeden z nich. Trzeba byś był pokornym, byś wystrzegał się pychy, szczytu wszelkiego zła" 54 .

Inne grzechy duchownych to, według Orygenesa, lekceważenie albo przynajmniej mniejsze poważanie biednych, a w stosunku do wiernych - swego rodzaju „wahanie się” między przesadzoną surowością i niemniej przesadną pobłaźliwością.

5. Konkluzje cząstkowe. Jeśli zbierzemy wskazania, których dostarcza Orygenes na temat kapłaństwa wiernych i kapłaństwa hierarchicznego, możemy wydobyć następujące itinerarium formacji prezbiterów. „Legitymacją” do wkroczenia na ten szlak jest ,zapalona pochodnia”, to znaczy słuchanie Słowa. Innym niezbędnym warunkiem są ,przepasane biodra” i „strój kapłański”, co oznacza życie nieposzlakowane i czyste: osoby stanu duchownego winny strzec się przede wszystkim pokus mieszczańskich nawyków, pychy, lekceważenia biednych, zbytniej surowości albo przesadzonej pobłażliwości. To co jest wymagane od kapłanów, to radykalne posłuszeństwo Panu i Jego Słowu, dystans od pokus tego świata, pełne braterstwo z ludem wiernych, poświęcenie i służba. Szczytem na drodze ku doskonałości - to znaczy metą procesu formacji kapłańskiej, jako że „hierarchia świętości” i „hierarchia widzialna” muszą się utożsamiać jedna z drugą - jest dla Orygenesa męczeństwo.

Nawiązując do „ognia na ofiarę całopalną”, to znaczy do wiary i znajomości Pisma świętego, które nigdy nie mogą zgasnąć na ołtarzu tego, kto wykonuje urząd kapłański $^{55}$ - Aleksandryjczyk dodaje:

„Każdy z nas ma w sobie nie týlko ogień, ma także ofiarę całopalną, i sam zapala sobie ogień na ołtarzu całopalenia, aby nieustannie płonął. Jeśli wyrzekam się wszystkiego, co posiadam, biorę swój krzyż i naśladuję Chrystusa, to składam swoją ofiarę całopalną na ołtarzu Boga; i jeśli wydam moje ciało na spalenie, mając miłość braterską, i osiągnę chwałę męczeństwa, to złożę ofiarę z samego siebie na ołtarzu Boga" ${ }^{56}$.

${ }^{52}$ In Isaiam hom. 7, 3, ed. W.A. Baehrens, GCS 33, 283.

53 In Iudices hom. 3, 2, ed. P. Messié - L. Neyrand - M. Borret, SCh 389, 100.

54 In Ezechielem hom. 9, 2, ed. M. Borret, SCh 352, 304-306.

55 Por. wyżej, przypis 35 i cały jego kontekst.

${ }^{56}$ In Leviticum hom. 9, 9, ed. M. Borret, SCh 287, 116. 
Są to słowa, które ukazują ogromną tęsknotę Orygenesa do chrztu krwi. W siódmej homilii o Księdze Sędziów, która pochodzi być może z czasów Filipa Araba (244-249), kiedy wydawała się już zacierać możliwość świadectwa krwi, Orygenes mówi: ,gdyby Bég pozwolił mi, abym został obmyty własną krwi, tak by dostąpić drugiego chrztu przyjmując śmierć dla Chrystusa, pewnie oddaliłbym się z tego świata..., ale błogosławieni są ci, którzy zasłużyli sobie na coś takiego" $" 57$.

Podsumujmy spostrzeżenia na temat całego Orygenesowego planu formacji kapłańskiej. Nie możemy uniknąć wrażenia, że w tym względzie, jak i w innych sprawach, stanowisko Orygenesa jest bardzo wymagające, jeśli nie radykalne ${ }^{58}$. Jego refleksje o kapłaństwie (podobnie jak u innych mistrzów aleksandryjskich: na przykład u Klemensa Aleksandryjskiego $)^{59}$, nawet jeśli wiążą między sobą bardzo wyraźnie „hierarchię urzędu kapłańskiego” z ,hierarchią doskonałości”, nie przedstawiają jednak duchownego jako swego rodzaju anioła: raczej sytuują go na drodze bardzo konkretnej ascezy codziennej, w walce z grzechem i złem. Aby podać przykład: stopniowe oderwanie się od świata, które musi charakteryzować formację kapłana, nie tłumaczy się w żadnym wypadku gorączkowym poszukiwaniem miejsca odseparowanego od świata, bo sam zaznacza:

„Nie w jakimś konkretnym miejscu trzeba szukać przybytku świętego, ale w uczynkach i w sposobie życia i w obyczajach: jeśli to zgadza się z wolą Bożą, jeśli pozostaje w zgodzie z przykazaniem Bożym, niewiele znaczy czy jesteś w domu, czy na rynku, tak mówię „na rynku”. Mało ważnym jest nawet to, czy jesteś

${ }^{57}$ In Iudices hom. 7, 2, ed. P. Messié - L. Neyrand - M. Borret, SCh 389, 180-182. O martyrologii Orygenesowej por. E. Dal Covolo, Appunti di escatologia origeniana con particolare riferimento alla morte e al martirio, ,Salesianum” 51 (1989) 769-784; tenże, Morte e martirio in Origene, „Filosofia e Teologia” 4 (1990) 287-294; tenże, Note sulla dottrina origeniana della morte, w: R.J. Daly (red.), Origeniana Quinta, Leuven 1992, 430-437; T. Baumeister, La teologia del martirio nella Chiesa antica, Torino 1995, 138-151 (także bibliografia, s. XXIX-XXXIX); E. Dal Covolo, Martirio, w: A. Monaci Castagno (red.), Origene. Dizionario, s. 266-268.

58 Chodzi o taki «radykalizm», który - zamiast łagodnieć z upływem czasu - umacnia się w pesymizmie i gorzkiej krytyce w miarę, jak Orygenes postępuje w latach, szczególnie po jego przeniesieniu z Aleksandrii do Cezarei, por. M. Simonetti, Origene e i mercanti nel tempio, w: A. Dupleix (red.), Recherches et Tradition. Mélanges patristiques offerts à Henri Crouzel S.J., Paris 1992, 271-284.

${ }^{59}$ Por. Stromata VI 13, 107, 2, GCS 52 4 , 485: „Stopnie hierarchiczne Kościoła tu na ziemi, biskupi, prezbiterzy, diakoni, myślę że są odzwierciedleniem (naśladownictwem) hierarchii anielskiej i tej ekonomii zbawienia, która, jak mówią Pisma, oczekuje tych, którzy za przykładem Apostołów żyją w doskonałej sprawiedliwości ewangelicznej”. 
w teatrze: jeśli służysz Słowu Boga, jesteś w świętym przybytku, do czego nie miej żadnych wątpliwości" ${ }^{60}$.

Ostatecznie tradycja aleksandryjska ubogaca w konkretność - w sposób może nawet nieoczekiwany - obraz pasterza nakreślony przez Ignacego z Antiochii i Jana Chryzostoma.

thum. Krzysztof Olaf Charamsa

\section{ESIGENZE DELLA FORMAZIONE ED IDENTITÀ SACERDOTALE Tra Antiochia ed Alessandria (II-IV s.)}

(Riassunto)

L'autore dell' articolo sta paragonando due antiche tradizioni orientali della formazione sacerdotale: antiochena rappresentata da Ignazio Antiocheno e da Giovanni Crisostomo, ed alessandrina illustrata coi testi di Origene (principalmente Omelie sul Levitico), che insegna chiaramente del sacerdozio dei fedeli e del sacerdozio ministeriale.

${ }^{60}$ In Leviticum hom. 12, 4, ed. M. Borret, SCh 287, 182. 